\title{
Extreme oxygen dynamics in shallow water of a fully marine Irish sea lough
}

\author{
Cynthia D. Trowbridge ${ }^{a, *}$, John Davenport ${ }^{b}$, Dylan M. Cottrell $^{\mathrm{a}}$, Luke Harman ${ }^{\mathrm{b}}$, Caitlin Q. Plowman $^{\mathrm{a}}$, \\ Colin Little ${ }^{c}$, Rob McAllen ${ }^{b}$
}

\author{
${ }^{a}$ Oregon Institute of Marine Biology, P.O. Box 5389, Charleston, OR 97420, USA \\ ${ }^{\mathrm{b}}$ School of Biological, Earth and Environmental Sciences, University College Cork, Enterprise Centre, \\ Distillery Fields, North Mall, Cork, Republic of Ireland \\ ${ }^{\mathrm{c}}$ Beggars Knoll, Long River Road, Newtown, Westbury, BA13 3ED, UK
}

\begin{abstract}
The benthos of Lough Hyne (Europe's first marine reserve) in SW Ireland has changed dramatically in the past decade with declining invertebrate communities and proliferating ephemeral macroalgae. In summer 2011 and 2012, we measured dissolved oxygen (DO) levels on shallow subtidal rocky shores of the lough and recorded both benthic hypoxia $\left(<2 \mathrm{mg} \mathrm{O}_{2} \mathrm{~L}^{-1}\right)$ and hyperoxia $\left(\sim 10-16 \mathrm{mg} \mathrm{O}_{2} \mathrm{~L}^{-1}\right)$. In late summer 2013, we systematically characterized the spatial and temporal patterns of DO in the lough seawater. Daytime DO levels were hyperoxic either at or near the rocky shore, declined with increased distance for the first $5 \mathrm{~m}$ offshore, then stabilized at normoxic levels $\left(\sim 8 \mathrm{mg} \mathrm{O}_{2} \mathrm{~L}^{-1}\right)$. DO levels above and below rocks were variable and often showed large differences (max. difference of $15.6 \mathrm{mg} \mathrm{O}_{2} \mathrm{~L}^{-1}$ ), particularly at rocky shore sites with low current flow. At night, the DO in shallow water declined, becoming hypoxic to anoxic during calm weather. These extreme oxygen fluctuations (i) are amongst the first records to report severe conditions within Irish coastal waters and (ii) could contribute to the known recent decline in benthic invertebrate diversity within the marine reserve.
\end{abstract}

Keywords: Hyperoxia $\bullet$ Hypoxia $\bullet$ Oxygen fluctuations $\bullet$ Lough Hyne $・$ Ireland $\bullet$ Marine reserve

\section{*Corresponding author:}

\section{E-mail: cdt@uoregon.edu}

Telephone: 001+541-574-0820

Mail: P.O. Box 1995, Newport, OR 97365 USA 


\section{Introduction}

The proliferation of (1) ephemeral macroalgae (particularly ulvoids and ectocarpoids) and (2)

microalgal/cyanobacterial biofilms has been documented in aquatic systems around the world in response to increased anthropogenic nutrients (fertilizers, sewage, etc.) [1-3]. Such algal and bacterial blooms produce extremes in dissolved oxygen (DO) by their high rate of photosynthesis during the day (producing hyperoxia), and the dominance of respiration at night (causing hypoxia).

Hyperoxic conditions (oxygen concentrations higher than in air-saturated seawater) can reduce activity levels, alter behavior, and reduce growth, fecundity, and survival of invertebrates [4-13]. Hyperoxia can also cause gas bubble disease in many types of fishes and invertebrates [14-18]. Adverse effects occur at supersaturation levels as low as 108-115\% [5, 6]. The Irish guidelines for bathing waters (S.I. No. 155 of 1992) are $<120 \%$ air saturation. The biotic consequences of naturally occurring values of $150-200 \%$ air saturation merit ecological study, particularly in marine reserves, SACs (Special Areas of Conservation), and other ecologically or economically sensitive areas.

Hypoxic and/or anoxic conditions can be lethal for both larval and adult invertebrates and fishes (e.g., [1928]). Although supersaturation of dissolved gases has been traditionally studied in artificial systems such as in aquaculture ponds and stream raceways, or around dams and power-plant outflows [14], both conditions (hyperand hypoxia) may also occur in 'natural' aquatic systems such as seagrass beds or macroalgal stands.

Extreme dissolved oxygen fluctuations have been reported for freshwater lakes [29], intertidal rockpools [18, 30-31], in various cnidarian-algal symbioses [32-35], near the surface of seaweed [36-39], and in shallow marine waters [12, 24, 40-41]. Hypoxia has also been extensively reviewed for (i) stratified lakes, fiords, and sea loughs, (ii) estuaries and inlets, and (iii) the oxygen minimum zone in deep water [42-47].

Researchers from the Irish Environmental Protection Agency found no evidence of summer hypoxia to anoxia in 95 coastal water bodies surveyed in Ireland (including several sites in County Cork) between 2003 and 2007 [48], although 10 were considered oxygen-deficient (2-6 $\left.\mathrm{mg} \mathrm{O}_{2} \mathrm{~L}^{-1}\right)$. Furthermore, a later analysis of Irish coastal and shelf waters in summer 2001 to 2009 reported the lowest seabed DO levels of about $6.3 \mathrm{mg} \mathrm{O}_{2} \mathrm{~L}^{-1}$ (70\% air saturation) [49]. Recently proposed Irish standards of DO in fully marine coastal waters range from about 6.3 to $10 \mathrm{mg} \mathrm{O}_{2} \mathrm{~L}^{-1}$ [50]. Yet the fully marine Lough Hyne in County Cork [42-47] and the brackish Arbear Salt Lake in County Galway [51] are both known to show periodic hypoxia $\left(<2 \mathrm{mg} \mathrm{L}^{-1}\right)$ and anoxia $(0$

$\mathrm{mg} \mathrm{L}^{-1}$ ). Because coastal hypoxia has not commonly been reported for Irish rocky shores and because Lough 
Hyne is an ecologically significant and internationally outstanding marine reserve [52-59], we embarked on a comprehensive program to quantify the large-scale and small-scale variations in the lough's shallow-water oxygen dynamics and to consider the ecological ramifications of such fluctuations.

Past research has been conducted on the oxygen tolerances of several ecologically significantly species that occur in the lough. For example, the embryos of the purple sea urchin (Paracentrotus lividus) are standardly used to assess European coastal water quality [60]; although embryos, larvae, and juveniles exhibit a high tolerance to low DO levels, survival and growth significantly decreases at $<2 \mathrm{mg} \mathrm{L}^{-1}[60$, Trowbridge et al., unpub. data]. Furthermore, the green urchin in Norway was 'unable to maintain high gonad growth' under DO conditions of 4 and $6 \mathrm{mg} \mathrm{L}^{-1}$ [61]. Juvenile spiny starfish (Marthasterias glacialis) exhibit reduced movement of podia, tenacity to substratum, and survival during 1-2 day exposures to hypoxia (Trowbridge et al., unpubl. data). Sessile suspension feeders such as cup corals, jewel anemones, and octocorals are uncommon in Lough Hyne habitats with DO values $<5-6 \mathrm{mg} \mathrm{L}^{-1}[62,63]$. The relationship between low DO levels and species mortality has already been established in Europe and elsewhere [21-22, 24, 27, 41, 44-45]; we investigated the severity of the DO problems in Lough Hyne in the present study.

We addressed two over-arching research questions. First, do hyperoxic and/or hypoxic conditions occur only along the rocky shoreline or also offshore into the body of the lough? The spatial extent of extreme DO levels would indicate which organisms could be affected: benthic invertebrates, fishes, and seaweed in shallow water or larvae, fishes, and other organisms in the water column offshore. Second, are shallow-water DO conditions within known lethal limits of marine species, particularly ecologically significant ones such as $P$. lividus?

\section{Material and Methods}

\subsection{Sea lough}

Lough Hyne $\left(51^{\circ} 30^{\prime} \mathrm{N}, 9^{\circ} 17^{\prime} \mathrm{W}\right)$ is a semi-enclosed, fully marine sea lough in County Cork, southwest Ireland. The lough is $\sim 0.8 \mathrm{~km}$ long and $\sim 0.5 \mathrm{~km}$ wide, has negligible freshwater input (salinity is generally 34 to 35 ), and is connected to the Atlantic Ocean by a shallow, narrow ( $25 \mathrm{~m}$ wide at high tide, $12 \mathrm{~m}$ at low tide) channel called the Rapids (Fig. 1). The tidal range within the lough is about a meter and appreciably larger outside (below the Rapids) [64]. The shallow sill in the Rapids restricts water flow into/out of the lough. The estimated flushing rate ranges between 12.5 and 41 days for the seawater above the thermocline [64-65]. Recent nutrient research [65] demonstrated significantly elevated nutrients relative to the 1990s [65-66]. Furthermore, 
the mass mortality of purple urchins has released macroalgae, both perennials and ephemerals, from grazing by a species previously described as a crucial and ecologically significant herbivore [53, 67].

The lough forms two different basins interconnected by the deep (48 m) Western Trough and shallow (1-2 m) eastern channel (Fig. 1). The south basin is nearest to the tidal rapids where seawater enters and exits the lough, whereas the north basin is partially separated from the south by Castle Island. The Western Trough becomes seasonally stratified with summer anoxia below the thermocline [42-44] and causes migration of mobile megafauna [68].

Discrete topographical and habitat units were designated in the 1930s on the shoreline (Fig. 1). These 108 marked sectors within the lough are still used because handheld GPS devices have difficulty obtaining satellite signals in several areas of the lough. The specific locations are designated by shore (west, south, east, north, and island) and sector numbers. Monitoring sites (10-m of shoreline) were established by Ebling et al. [69] and relocated and resurveyed by Little et al. [70]. Ten sites (of the original 20) have been surveyed for $>30$ target species every year since the early 1990s [71-74]. Thus, the rocky shores of the lough have been extensively studied.

\subsection{Spatial variation in dissolved oxygen}

\subsubsection{Onshore-offshore profiles}

To determine how spatially localized DO values were, one site was selected on each shore of the lough (north, south, east, and west) and a 50-m transect was laid out perpendicular to the shore at the chosen site. This procedure was repeated, with three transects being completed per day on two different occasions (27 Aug and 13 Sep 2013) (Fig. 1a). For the first five meters offshore, physical measurements (water temperature, dissolved oxygen concentration $\left[\mathrm{mg} \mathrm{O}_{2} \mathrm{~L}^{-1}\right]$, and depth of the benthos) were taken every meter, using a recently calibrated optical YSI ProODOTM probe, meter stick (shallow depths) and a hand-held, high-frequency digital depth sounder ( $>1 \mathrm{~m}$ depths). From $5 \mathrm{~m}$ to $50 \mathrm{~m}$ offshore, the water column was generally deep enough $(>0.5 \mathrm{~m})$ that the ephemeral algae were patchy (or absent) and physical measurements were taken every $5 \mathrm{~m}$. For each location, DO readings were taken at water depths of $1 \mathrm{~cm}$ ('surface') and $15 \mathrm{~cm}$ ('subsurface'). Each transect took about $20 \mathrm{~min}$ and was done between 1400 and $1600 \mathrm{~h}$.

To analyze these profiles, we considered how DO (dependent variable) varied with four independent variables (monitoring site, distance offshore, sampling depth, and bottom depth) by using a general linear model 
(GLM) test. The assumptions of this analysis were assessed as follows. (i) DO readings were assumed to be independent given the continuous water movement within the lough. (ii) Collinearity was investigated by determining which variables were strongly correlated. Because distance offshore and bottom depth were significantly correlated (Pearson's correlation, $r=0.826, n=180, p<0.001$ ), we dropped the latter variable from our tested model. (iii) We inspected the residuals to ensure there was no problem with variances. Because the residuals were problematic for the surface DO, subsurface DO, and the combined data, we used nonparametric Spearman rank correlations to test how DO varied with distance offshore for surface and subsurface sampling locations.

DO profiles were conducted on both sides of all 10 long-term monitoring sites (Fig. 1b) of Little et al. [7072]. The same methods used in the 50-m profiles (above) were repeated for the 5-m profile study, though measurements were taken only from 0 to $5 \mathrm{~m}$ offshore. For every meter offshore, DO readings were taken at depths of 1 and $15 \mathrm{~cm}$, and the depth of the sea bed was recorded. Each transect took about 10 min and was done between 1030 and 1630 h. To analyze these profiles, we considered the same three assumptions as above. Because distance offshore and bottom depth were again significantly correlated (Pearson correlation, $r=0.614$, $n=120, p<0.001$ ), we removed the latter variable from our tested model. Furthermore, because DO at surface and subsurface depths were highly correlated $(r=0.954, n=107, p<0.001)$, we simplified our model to two independent variables: site and distance offshore. As before, we inspected the residuals; after confirming there was no problem with variances, we conducted a 2-factor GLM with site and distance offshore as factors.

\subsubsection{Above and below rocks}

In August and September 2011, we noted that several long-term monitoring sites were becoming hypoxic to anoxic, particularly under shallow subtidal rocks. Therefore, we selected two sites that had appeared most oxygen-stressed, namely East Castle (sector I9) and East Goleen (W36). We measured DO concentrations directly below the water surface, above the seaweed patches, in the middle of seaweed clumps, and then directly above and below small slabs of rocks (10 per site) directly next to the monitoring sites. Rocks were lifted as little as possible ( $<5 \mathrm{~cm}$ off the benthos) to limit water flow and, thus, changes in DO values.

In August and September 2013, oxygen levels above and under rocks were again measured, but more comprehensively. We selected 5 of the 10 long-term monitoring sites (Fig. 1d): East Castle (sector I9), North Labhra (I1), Codium Bay (S16), SE Labhra (I15), and Westwood South (W21/22). To avoid disturbing the monitoring sites, we sampled rocks in 3-m sections directly adjacent to the sites. DO readings were taken $1 \mathrm{~cm}$ 
above the selected rocks and then immediately under the same rocks during daytime low tides. Rocks were selected to have roughly the same surface area (approx. $400 \mathrm{~cm}^{2}$ ) when viewed from above and to be lying on top of other rocks, thus ensuring that the oxygen probe did not penetrate benthic sediment. A minimum of 10 rocks were selected in the 3-m section laterally flanking each site, for a total of at least 20 rocks per site. This design allowed for a comparison of small-scale variability within sites as well as large-scale variability among sites. All measurements were taken at or near daytime low tide between 1030 and $1630 \mathrm{~h}$ to ensure that the selected rocks were in the shallow subtidal region. Because cloud cover and weather was more important than time of day during the late morning to late afternoon period, we did not include time of day as a factor in the analysis. To analyze the resulting DO values, we used a 2-way ANOVA statistical design with site and side (right vs. left) as factors and water depth as a covariate.

\subsection{Temporal variation in dissolved oxygen}

To document nocturnal and diurnal variation, we measured DO (in $\mathrm{mg} \mathrm{O}_{2} \mathrm{~L}^{-1}$ ) with the YSI optical probe at 4-h intervals through a 24-h period in mid-summer (19-20 July 2012) at two sites: (a) North shore in sector N6 and (b) West shore at sector W6 (Fig. 1c). We also recorded surface temperature and range of depths at which measurements were made (60-110 cm overall). At both sites there was patchy ulvoid seaweed, distributed down to a depth of about $1 \mathrm{~m}$ below low tide level, thus forming a band covering the intertidal and a portion of the subtidal. This green seaweed was interspersed with dead ephemeral algae and gravelly substratum. All of our 'tuft' measurements were in ulvoid beds. We obtained wind speed data from Met Éireann for the nearby Sherkin Island for this time period as a relative measure of wind disturbance at the lough.

To determine whether the mid-summer oxygen extremes would persist in late summer, we deployed a recently calibrated HOBO oxygen data logger (U26-001 by Onset) for $24 \mathrm{~h}$. First, we set the sensor near the top of the Rapids (sector S16, Fig. 1c) during 16-17 September 2013. Second, we deployed the sensor on the North Shore (sector N11, Fig. 1c) during 19-20 September. In both cases, the sensor was set to record every 15 min, then attached to bricks with cable ties, and placed in shallow subtidal areas (ca. $1 \mathrm{~m}$ deep at low tide). We again obtained wind speed data from Met Éireann for the nearby Sherkin Island as a relative measure of wind disturbance at the lough.

\section{Results}

3.1 Spatial variation in dissolved oxygen 


\subsubsection{Onshore-offshore profiles}

In 2013, daytime DO levels were markedly hyperoxic (up to $14 \mathrm{mg} \mathrm{O}_{2} \mathrm{~L}^{-1}$ ) either at or near the shore. DO levels declined with increased distance from shore in the first $5 \mathrm{~m}$ (Fig. 2a-b); then oxygen stabilized at normoxic levels $\left(\sim 8 \mathrm{mg} \mathrm{O}_{2} \mathrm{~L}^{-1}\right)$. The effect of distance offshore was highly significant (Spearman rank correlation, $r_{s}=-0.769, n=90, p<0.001$ for surface water $(1 \mathrm{~cm}) ; r_{s}=-0.797, n=84, p<0.001$ for subsurface water $(15 \mathrm{~cm}))$. We noted these results generally reflected the underlying distribution of benthic macroalgae (perennial and ephemeral) in the nearshore environment although unfortunately we did not quantify the presence or absence of algae at the time.

There was significant spatial variation in DO values measured at the 10 monitoring sites in 2013. Most of the variation was among sites $\left(F_{(9,60)}=28.5, p<0.001\right)$ with Boundary Bay (E14), East Castle (I9) and SE Labhra (I15) having the highest DO values. There were also highly significant differences in DO with distance (0 to $5 \mathrm{~m})$ from shore $\left(F_{(5,60)}=10.7, p<0.001\right)$ with maximal DO typically at $1 \mathrm{~m}$ from the shoreline and a decline to normoxic conditions by $5 \mathrm{~m}$. Site and distance from shore accounted for $85 \%$ of the variation in DO values measured.

\subsubsection{Above and below rocks}

In 2011, the mean DO values in the water column, at the water/macroalgal interface, and on the benthos were slightly hyperoxic, but $<10 \mathrm{mg} \mathrm{O}_{2} \mathrm{~L}^{-1}$ (Fig. 3a). In the middle of the ephemeral algal beds (mostly the phaeophytes Stilophora and ectocarpoids), DO values were on average 13-14 $\mathrm{mg} \mathrm{O}_{2} \mathrm{~L}^{-1}$ with considerable variation. All these values were substantially greater than those under the rocks (mean $<1 \mathrm{mg} \mathrm{O}_{2} \mathrm{~L}^{-1}$ ) at East Castle and East Goleen sites (Fig. 3a).

In 2013, differences in DO levels above and below rocks were variable but often large—with a maximum difference for an individual rock of $15.6 \mathrm{mg} \mathrm{O}_{2} \mathrm{~L}^{-1}$. SE Labhra and Westwood South had smaller differences in oxygen levels above and below rocks than East Castle, North Labhra, and Codium Bay (Fig. 3b). The former two sites had higher flow rates than the latter three sites (Trowbridge, unpubl.data). There were six rocks that were hypoxic $\left(<2 \mathrm{mg} \mathrm{O}_{2} \mathrm{~L}^{-1}\right)$ or anoxic underneath; all of these rocks were at the latter three sites. In general, however, the low-oxygen conditions were not as extreme during the 2013 sampling as during the 2011 survey (see East Castle in Fig. 3).

There were highly significant differences in DO levels above rocks among the 5 study sites (ANOVA, $F_{(4,90)}=76.3, p<0.001$ ). Although there was no significant main effect of local scale (right vs. left side of study 
site, $\left.F_{(1,90)}=1.6, p=0.210\right)$, there was a highly significant interaction effect $\left(F_{(4,90)}=6.3, p<0.001\right)$. The water depth of the benthos was not a significant factor $\left(F_{(1,90)}=1.9, p=0.170\right)$ explaining DO levels above rocks. Below rocks, however, both site and side of site (right vs. left) were significant factors $(p=0.001$ and 0.003 , respectively), whereas the interaction and water depth were not ( $p=0.276$ and 0.059 , respectively).

\subsection{Temporal variation}

In July 2012, DO levels fluctuated widely with time of day (by up to $12 \mathrm{mg} \mathrm{O}_{2} \mathrm{~L}^{-1}$ ), but the results were consistent between the two sites (Fig. 4). In late morning (1100 h BST), the ephemeral algae and interface above them were very hyperoxic, but the surface water was close to normoxic. At $1500 \mathrm{~h}$ and $1900 \mathrm{~h}$, the whole water column was hyperoxic. An hour after sunset $(2300 \mathrm{~h})$ the algae had become suboxic, while the surface water remained rather hyperoxic. At $0300 \mathrm{~h}$, the seaweed environment was hypoxic and the water column above it also exhibited reduced DO (though only slightly at the surface some 50-80 cm above). Even 1 hour after sunrise, the seaweed DO was still substantially reduced on the north shore. The mean wind speed (at nearby Sherkin Island) during this period was $12.7 \mathrm{~km} \mathrm{~h}^{-1}$.

The magnitude of temporal fluctuations of DO varied with weather during our 2013 HOBO sampling (Fig. 5). During the 16-17 Sep. survey (Fig. 5b), diurnal-nocturnal fluctuations in DO were not very large: the water was hyperoxic in the day but normoxic at night at Codium Bay on the south shore (S16). Extremely strong winds developed in late afternoon and, despite the steep hills around Lough Hyne, produced large waves in the lough that lasted throughout the night and next morning. The mean wind speed recorded at the nearby Sherkin Island weather station was $37.5 \mathrm{~km} \mathrm{~h}^{-1}$. Calmer conditions (wind speed $21.5 \mathrm{~km} \mathrm{~h}^{-1}$ ) occurred during the 19-20 Sep. survey (Fig. 5a), and daytime hyperoxia (up to $16 \mathrm{mg} \mathrm{O}_{2} \mathrm{~L}^{-1}$ ) was recorded on the north shore (N11) and hypoxia to anoxia developed at night. In the middle of the night, oxygen levels rose (during the low tide) before returning to hypoxia. Even though the sensor remained submerged, the water was shallow enough (ca. $0.5 \mathrm{~m})$ that oxygenation may have occurred across the air-water interface. As the tide level subsequently rose, the water at the benthos became hypoxic again until after sunrise (Fig. 5a). This calm-weather pattern of DO was similar to our mid-summer 2012 results (Fig. 4).

\section{Discussion}

4.1 Spatial patterns 
Extreme oxygen conditions (hyperoxia and/or hypoxia) occurred along the shoreline of Lough Hyne but not offshore into the body of the lough (the epilimnion). DO levels exhibited both small-scale and large-scale differences. This type of variation was expected, as the amount of ephemeral algae and benthic biofilms varied within and among sites, based on physical differences among sites [63]. Shore slope (of the shallow subtidal) varied among sites from $3.4^{\circ}$ to $41.5^{\circ}$ from the horizontal; fetch varied from $34 \mathrm{~m}$ to $884 \mathrm{~m}$; aspect varied from $60^{\circ}$ to $345^{\circ}$ (from a north compass bearing); and four sites had tree canopy reducing light levels whereas six sites did not. Furthermore, some sites were relatively similar on the two ends whereas others (such as Boundary Bay) had dramatically different depth profiles and current flows at either end of the 10-m wide sites.

Fluctuations in local DO levels could, in turn, influence benthic community structure. If these fluctuations occur with a great enough frequency and/or amplitude, the entirety of Lough Hyne's shallow subtidal community could be altered (see review by Diaz and Rosenberg [24] regarding predicted biotic effects). Such alteration has already started since the early 2000s: (1) unprecedented proliferation of ephemeral algae and (2) massive mortality of suspension feeders (sponges, bryozoans, hydroids), and mobile invertebrates [63, Little and Trowbridge, pers. obs.]. Mobile animals subjected to stressful conditions may be driven into deeper water or away from the shore comparable to the habitat compression caused by seasonal anoxia below the thermocline [68]. Several Atlantic and Pacific urchin species exhibit significantly reduced growth, gonad development, and survival as well as abnormal embryonic and larval development under hypoxic conditions [60-61, 75]. The DO levels at night on the shore as well as under shallow subtidal rocks in Lough Hyne (Fig. 3-5) were clearly low enough to negatively affect purple urchins and juvenile starfish that dwell there and to have negative effects on urchin reproduction, embryonic and larval development, and juvenile recruitment.

Habitat degradation and oxygen fluctuations within the lough may have contributed to the mass mortality of urchins in the lough [71-73] as well as the demise of many sessile invertebrates. While snorkelling in late summer, we have frequently seen (1) large lobsters that have emerged from their lairs onto shallow-water, defaunated benches during the daytime as well as (2) rotting remains of purple urchins, large crabs, and other ecologically significant consumers. These types of observations are reminiscent of the 'graveyard phenomenon' described by Stachowitsch [76-77] for the mass mortalities of macro-epifaunal communities in the Gulf of Trieste in the Adriatic Sea.

However, not all invertebrates are negatively affected by ephemeral algal blooms. For example, Waheed [78] experimentally demonstrated that some species derived refuge from predators within ectocarpoid blooms. How hypoxia will affect larval recruitment and energy transfer up through the food web will depend on two 
factors: (1) oxygen tolerance as well as (2) prey vs predator stress tolerance. With respect to the former, hypoxic-tolerant species may continue to settle and survive; our preliminary acrylic plate experiments indicated that some errant polychaetes and barnacles settled more abundantly in the presence of ephemeral algae than in their absence (both algal removal and unmanipulated control); bivalves and bryozoans, however, showed the opposite response. With respect to the latter issue, when prey species are more vulnerable to stress than their predators are, the resulting outcomes of species interactions would differ from when predators are more vulnerable than prey (e.g. prey-stress vs. consumer-stress models of Menge and Olson [79]).

In their review of supersaturation in aquatic systems, Weitkamp and Katz [14] acknowledged that photosynthesis could contribute to supersaturated water and, thus, to gas bubble disease. The DO values documented in Lough Hyne substantially exceed US and Irish Environmental Protection Authority supersaturation standards. Because Lough Hyne is a marine reserve with significant fish, invertebrate, and seaweed communities [52-59], the frequency and magnitude of hyperoxic and hypoxic events is of considerable conservation concern, particularly given the preservation objectives of the National Parks and Wildlife Service [59]. Comparable oxygen problems and conservation concerns have been reported for seagrass meadows in Barloge Creek (Trowbridge et al., unpublished data) and elsewhere [80]. The generality of these DO results to other systems depends on coastal configuration; many geographic regions have highly convoluted coastlines forming semi-enclosed bays, estuaries, loughs, sloughs, etc. that would be susceptible to eutrophication-driven hypoxia and hyperoxia. Diaz and Rosenberg [24] reported that $>400$ coastal systems in the world were dead zones associated with eutrophication: it is a general phenomenon.

\subsection{Temporal patterns}

Diel-cycling hypoxia has been reported in several systems. In Lough Hyne, when weather conditions were calm (Fig. 4 and Fig. 5b), benthic species in nearshore habitats experience extreme DO conditions that could be lethal/sublethal to sessile biota. Alternatively, extreme hypoxia might drive animals out of the degraded habitats. Strong winds and waves coincided with the 16-17 Sep 2013 sampling (Fig. 5a) and do not reflect normal lowflow conditions of mid-summer at Lough Hyne. Winds mixed the water in the shallow subtidal, moderating the hyperoxia and hypoxia. If winds and/or water currents were strong enough, DO levels which were typically elevated above ephemeral algae and depressed below it could be homogenized, with likely beneficial effects on the subtidal benthic communities. In other regions, Breitburg [81] reported that wind and tides influenced the severity of hypoxic events, and Tyler and Targett [82] reported tidal-related variation in DO extremes. Further 
studies are needed to gain a greater understanding of how shallow subtidal DO levels vary temporally. We hypothesize that wind waves will ameliorate potential hypoxia, whereas calm spells will exacerbate the stress in low-energy systems with long residence times of seawater (e.g. Lough Hyne).

Late summer to early autumn conditions may be extreme but what about the rest of the year? Our ongoing temporal analysis of DO at several sites has indicated extreme DO fluctuations for much of the year. For example, fluctuations at one site in April 2014 ranged from $<1$ to $>20 \mathrm{mg} \mathrm{O}_{2} \mathrm{~L}^{-1}$ within a 24-hour period (Plowman et al., unpublished data). While mobile animals (fishes and invertebrates) can move offshore to avoid the stressful conditions, sessile invertebrates such as sponges, ascidians, hydroids, and bryozoans will be subjected to sublethal /lethal conditions. Field experiments are ongoing to evaluate how such hypoxia and hyperoxia affect larval settlement and adult survivorship (Trowbridge et al., unpublished data). The primary objective of the present study was to demonstrate the severity of DO problems within Ireland's only marine reserve and Europe's first one.

Recovery from hypoxia is influenced by three factors: reduced nutrient enrichment, stratification of the water, and freshwater runoff [24]. In Lough Hyne — and many other coastal systems - the nutrient enrichment is apparently not autochthonous [65], so reduction is not under local control. The strength of shallow-water stratification depends largely on weather. Finally, although Lough Hyne has little freshwater input, unusually wet years do result in localized ulvoid blooms that exacerbate the oxygen dynamics. Potential remedial measures include the restocking of purple sea urchins (Paracentrotus lividus) into Lough Hyne to control the macroalgae. However, the efficacy of such restoration efforts would be dependent on the (i) absence of urchin pathogens and (ii) effective enforcement of the "no-take" regulations of urchins and other shellfish. Without intervention, the high nutrient levels and lack of effective grazers will probably continue, leading to alternating hypoxia and hyperoxia in the reserve, with negative consequences for the lough's shallow-water ecosystem.

\section{Acknowledgments}

We are grateful to D. O'Donnell and P. Graham of the National Parks and Wildlife Service for permission to carry out scientific research in the Lough Hyne Marine Reserve. We thank P. Stirling, T. Kearney, B. DlouhyMassengale, M. Pauling, S. Phillips and C. Zucker for assistance in the field and extensive discussions in the lab. B. Bingham (WWU) kindly advised us about the statistics. We thank the 2013 IRES team for their help and support. The paper was substantially improved by comments and suggestions of anonymous reviewers. CDT, RM, DC, CQP, and CL were supported in part by NSF grant INT-1130978 awarded to CDT. Any opinions, 
findings and conclusions or recommendations expressed in this material are those of the authors and do not necessarily reflect the views of the National Science Foundation.

\section{References}

[1] Valiela, I., McClelland, J., Hauxwell, J., Behr, P.J., Hersh, D., Foreman, K. 1997. Macroalgal blooms in shallow estuaries: controls and ecophysiological and ecosystem consequences. Limnol. Oceanogr. 42, 1105-1118.

[2] Nelson, T.A., Nelson, A.V., Tjoelker, M. 2003. Seasonal and spatial patterns of "green tides" (ulvoid algal blooms) and related water quality parameters in the coastal waters of Washington State, USA. Bot. Mar. 46, 263-275.

[3] Lyons, D.A., Arvanitidis, C., Blight, A.J., Chatzinikolaou, E., Guy-Haim, T., Kotta, J., Orav-Kotta, H., Queir, A.M., Rilov, G., Somerfield, P.J., Crowe, T.P. 2014. Macroalgal blooms alter community structure and primary productivity in marine ecosystems. Glob. Change Biol. 20, 2712-2724.

[4] Torres, J.J., Mangum, C.P. 1974. Effects of hyperoxia on survival of benthic marine invertebrates. Comp. Biochem. Physiol. 47A,17-22.

[5] Bisker, R., Castagna, M. 1985. The effect of various levels of air-supersaturated seawater on Mercenaria mercenaria (Linné), Mulinia lateralis (Say), and Mya arenaria Linné, with reference to gas-bubble disease. J. Shellfish Res. 5, 97-102.

[6] Bisker, R., Castagna, M. 1987. Effect of air-supersaturated seawater on Argopecten irradians concentricus (Say) and Crassostrea virginica (Gmelin). J. Shellfish Res. 6, 79-83.

[7] Bisker, R., Castagna, M. 1988. The effect of air-supersaturated sea-water on Argopecten irradians (Lamarck) and Crassostrea virginica (Gmelin) with reference to gas bubble trauma. J. Shellfish Res. 7, 150.

[8] Huntington, K.M., Miller, D.C. 1989. Effects of suspended sediment, hypoxia, and hyperoxia on larval Mercenaria mercenaria (Linnaeus, 1758). J. Shellfish Res. 8, 37-42.

[9] Abele-Oeschger, D., Oeschger, R. 1995. Enzymatic antioxidant protection in spawn, larvae and adult worms of Phyllodoce mucosa (Polychaeta). Ophelia 43, 101-110.

[10] Timmins, G.S., Penatti, C.A.A., Bechara, E.J.H., Swartz, H.M. 1999. Measurement of oxygen partial pressure, its control during hypoxia and hyperoxia, and its effect upon light emission in a bioluminescent elaterid larva. J. Exp. Biol. 202, 2631-2638. 
[11] Harris, J.O., Burke, C.M., Edwards, S.J., Johns, D.R. 2000. Effect of oxygen supersaturation and temperature on juvenile greenlip, Haliotis laevigata, and blacklip, Haliotis rubra, abalone. J. Shellfish Res. $19,518$.

[12] da Rosa, C.E., de Souza, M.S., Yunes, J.S., Proença, L.A.O., Nery, L.E.M., Monserrat, J.M. 2005. Cyanobacterial blooms in estuarine ecosystems: Characteristics and effects on Laeonereis acuta (Polychaeta, Nereididae). Mar. Biol. Poll. 50, 956-964.

[13] Lardies, M.A., Fernández, M. 2002. Effect of oxygen availability in determining clutch size in Acanthina monodon. Mar. Ecol. Prog. Ser. 239, 139-146.

[14] Weitkamp, D.E., Katz, M. 1980. A review of dissolved gas supersaturation literature. Trans. Amer. Fish. Soc. $109,659-702$.

[15] Edsall, D.A., Smith, C.E. 1991. Performance of rainbow trout and Snake River cutthroat trout reared in oxygen super-saturated water. Aquaculture 90, 251-259.

[16] Lygren, B., Hamre, K., Waagbø, R. 2000. Effect of induced hyperoxia on the antioxidant status of Atlantic salmon Salmo salar L. fed three different levels of dietary vitamin E. Aquacult. Res. 31, 401-407.

[17] Espmark, A.M., Hjelde, K., Baeverfjord, G. 2010. Development of gas bubble disease in juvenile Atlantic salmon exposed to water supersaturated with oxygen. Aquaculture 306, 198-204.

[18] Phillips, N.E., Moran, A.L. 2015. Oxygen production from macrophytes decreases development time in benthic egg masses of a marine gastropod. Hydrobiologia 757, 251-259. doi:10.1007/s10750-015-2256-7.

[19] Baker, S.M., Mann, R. 1992. Effects of hypoxia and anoxia on larval settlement, juvenile growth, and juvenile survival of the oyster Crassostrea virginica. Bio. Bull. 182, 265-269.

[20] Levin, L.A., Gage, J.D., Martin, C., Lamont, P.A. 2000. Macrobenthic community structure associated with the oxygen minimum zone, NW Arabian Sea. Deep-Sea Res. Part II 47, 189-226.

[21] Levin, L.A., Ekau, W., Gooday, A.J., Jorissen, F., Middelburg, J.J., Naqvi, S.W.A., Neira, C., Rabalais, N.N., Zhang, J. 2009. Effects of natural and human-induced hypoxia on coastal benthos. Biogeosciences 6, 2063-2098.

[22] Gray, J.S., Wu, R.S., Or, Y.Y. 2002. Effects of hypoxia and organic enrichment on the coastal marine environment. Mar. Ecol. Prog. Ser. 238, 249-279.

[23] Cheung, S.G., Chan, H.Y., Liu, C.C., Shin, P.K.S. 2008. Effect of prolonged hypoxia on food consumption, respiration, growth and reproduction in the marine scavenging gastropod Nassarius festivus. Mar. Poll. Bull. 57, 280-286. 
[24] Diaz, R.J., Rosenberg, R. 2008. Spreading dead zones and consequences for marine ecosystems. Science $321,926-929$.

[25] Ekau, W., Auel, H., Pörtner, H.-O., Gilbert, D. 2010. Impacts of hypoxia on the structure and processes in pelagic communities (zooplankton, macro-invertebrates and fish). Biogeosciences 7, 1669-1699.

[26] Matabos, M., Tunnicliffe, V., Juniper, S.K., Dean, C. 2012. A year in hypoxia: epibenthic community responses to severe oxygen deficit at a subsea observatory in a coastal inlet. PLoS ONE 7: e45626. doi:10.1371/journal.pone.0045626

[27] Riedel, B., Padas, T., Pretterebner, K., Schiemer, L., Steckbaurer, A., Haselmair, A., Zuschin, M., Stachowitsch, M. 2014. Effect of hypoxia and anoxia on invertebrate behaviour: ecological perspectives from species to community level. Biogeosciences 11, 1491-1518.

[28] Riedel, B., Zuschin, M., Stachowitsch, M. 2012. Tolerance of benthic macrofauna to hypoxia and anoxia in shallow coastal seas: a realistic scenario. Mar. Ecol. Prog. Ser. 458, 39-52.

[29] Seki, H., Takahashi, M., Hara, Y., Ichimura, S. 1980. Dynamics of dissolved oxygen during algal bloom in Lake Kasumigaura, Japan. Water Res. 14, 179-183.

[30] Stephenson, T.A., Zoond, A., Eyre, J. 1934. The liberation and utilisation of oxygen by the population of rock-pools. J. Exp. Biol. 11, 162-172.

[31] Truchot, J.-P., Duhamel-Jouve, A. 1980. Oxygen and carbon dioxide in the marine intertidal environment: diurnal and tidal changes in rockpools. Resp. Physiol. 39, 241-254.

[32] Dykens, J.A., Shick, J.M. 1982. Oxygen production by endosymbiotic algae controls superoxide dismutase activity in their animal host. Nature 297, 579-580.

[33] Dykens, J.A. 1984. Enzymic defenses against oxygen toxicity in marine cnidarians containing endosymbiotic algae. Mar. Biol. Lett. 5, 291-301.

[34] Richier, S., Merle, P.-L., Furla, P., Pigozzi, D., Sola, F., Allemand, D. 2003. Characterization of superoxide dismutases in anoxia- and hyperoxia-tolerant symbiotic cnidarians. Biochim. Biophys. Acta 1621, 84-91.

[35] Richier, S., Furla, P., Plantivaux, A., Merle, P.-L., Allemand, D. 2005. Symbiosis-induced adaptation to oxidative stress. J. Exp. Biol. 208, 277-285.

[36] Kaspar, H.F. 1992. Oxygen conditions on surfaces of coralline red algae. Mar. Ecol. Prog. Ser. 81, 97-100.

[37] Collén, J., Davison, I.R. 1999. Reactive oxygen production and damage in intertidal Fucus spp. (Phaeophyceae). J. Phycol. 35, 54-61. 
[38] Irwin, S., Davenport, J. 2002. Hyperoxic boundary layers inhabited by the epiphytic meiofauna of Fucus serratus. Mar. Ecol. Prog. Ser. 244, 73-79.

[39] Irwin, S., Davenport, J. 2010. Oxygen microenvironment of coralline algal tufts and their associated epiphytic animals. Biology and environment. Proc. Roy. Ir. Acad. 110B, 185-193.

[40] Tunnicliffe, V. 1981. High species diversity and abundance of the epibenthic community in an oxygendeficient basin. Nature 294, 354-356.

[41] Vaquer-Sunyer, R., Duarte, C.M. 2008. Thresholds of hypoxia for marine biodiversity. Proc. Natl. Acad. Sci. $105,15452-15457$.

[42] Kitching, J.A., Ebling, F.J., Gamble, J.C., Hoare, R., McLeod, A.A.Q.R., Norton, T.A. 1976. The ecology of Lough Ine. XIX. Seasonal changes in the Western Trough. J. Anim. Ecol. 45, 731-758.

[43] Thain, V.M., Jones, J., Kitching, J.A. 1981. Distribution of zooplankton in relation to the thermocline and oxycline in Lough Ine, County Cork. Ir. Nat. J. 20, 292-295.

[44] McAllen, R., Davenport, J., Bredendieck, K., Dunne, D. 2009. Seasonal structuring of a benthic community exposed to regular hypoxic events. J. Exp. Mar. Biol. Ecol. 368, 67-74.

[45] Rabalais, N.N., Díaz, R.J., Levin, L.A., Turner, R.E., Gilbert, D., Zhang, J. 2010. Dynamics and distribution of natural and human-caused hypoxia. Biogeosciences 7, 585-619.

[46] Sullivan, T., Broszeit, S., O’Sullivan K.P.A., McAllen, R., Davenport, J., Regan, F. 2013. High resolution monitoring of episodic stratification events in an enclosed marine system. Est. Coast. Shelf Sci. 123, 26-33.

[47] Sullivan, T., Byrne, C., Harman, L., Davenport, J., McAllen, R., Regan, F. 2014. Determination of spatial and temporal variability of $\mathrm{pH}$ and dissolved oxygen concentrations in a seasonally hypoxic semi-enclosed marine basin using continuous monitoring. Anal. Methods 6, 5489-5497.

[48] O’Boyle, S., McDermott, G., Wilkes, R. 2009. Dissolved oxygen levels in estuarine and coastal waters around Ireland. Mar. Poll. Bull. 58, 1657-1663.

[49] O’Boyle, S., Nolan, G. 2010. The influence of water column stratification on dissolved oxygen levels in coastal and shelf waters around Ireland. Proc. Roy. Irish Acad. 110B, 195-209.

[50] EPA. 2007. Water Framework Directive. Proposed quality standards for surface water classification: a discussion document for public consultation. Wexford, Environmental Protection Agency.

[51] Henry, L.M., Kennedy, R., Keegan, B.F. (2008) An investigation of periodic hypoxia at Ardbear Salt Lake. J. Mar. Biol. Assoc. U.K. 88, 1297-1307.

[52] Kitching, J.A. 1975. The importance of Lough Ine as a site for marine conservation. An Taisce, Cork. 
[53] Kitching, J.A. 1987a. Ecological studies at Lough Hyne. Adv. Ecol. Res. 17, 115-186.

[54] Kitching, J.A. 1987b. Lough Ine - Classic sites. Biologist 34, 235-239.

[55] Minchin, D. 1987. Fishes of the Lough Hyne marine reserve. J. Fish Biol. 31, 343-352.

[56] Myers, A.A., Little, C., Costello, M.J., Partridge, J.C. 1991. The ecology of Lough Hyne. R. Irish Acad., Dublin.

[57] Bell, J.J., Shaw, C. 2001. Lough Hyne: a marine biodiversity hotspot? In: Nunn JD (ed) Marine biodiversity in Ireland and adjacent waters. pp 35-43.

[58] Kearney, T. 2013. Lough Hyne: From Pre-History to the Present. Macalla Publishing, Ireland.

[59] NPWS. 2014. Conservation objectives: Lough Hyne Nature Reserve and environs SAC 000097. Ver. 1. National Parks and Wildlife Service, Dublin.

[60] Saco-Álvarez, L., Durán, I., Lorenzo, J.I., Beira, R. 2010. Methodological basis for the optimization of a marine sea-urchin embryo test (SET) for the ecological assessment of coastal water quality. Ecotoxic. Environ. Saf. 73, 491-499.

[61] Siikavuopio, S.I., Dale, T., Mortensen, A., Foss, A. 2007. Effects of hypoxia on feed intake and gonad growth in the green sea urchin, Strongylocentrotus droebachiensis. Aquaculture 266, 112-116.

[62] Trowbridge, C.D., Little, C., Ferrenburg, L.S., Resk, H.M., Kachmarik, K., Plowman, C.Q., Stirling, P., \& McAllen, R. 2016. Shallow subtidal octocorals in an Irish marine reserve. Mar. Biodivers. 46, 879-887.

[63] Trowbridge, C.D., Kachmarik, K., Plowman, C.Q., Little, C., Stirling, P., McAllen, R. 2017. Biodiversity of shallow subtidal, under-rock invertebrates in Europe's first marine reserve: Effects of physical factors and scientific sampling. Est. Coast. Shelf Sci. 187, 43-52.

[64] Bassindale, R., Davenport, E., Ebling, F.J., Kitching, J.A., Sleigh, M.A., Sloane, J.F. 1957. The ecology of the Lough Ine Rapids with special reference to water currents: VI. Effects of the Rapids on the hydrography of the South Basin. J. Ecol. 45, 879-900.

[65] Jessopp, M., McAllen, R., O'Halloran, J., Kelly, T.C. 2011. Nutrient and ecosystem dynamics in Ireland's only marine nature reserve (NEIDIN). STRIVE Report Series 66. Environmental Protection Agency, Ireland. http://www.epa.ie/downloads/pubs/research/biodiversity/-STRIVE_66_Jessopp_NEIDIN_web.pdf. Accessed 14 Apr 2015.

[66] Johnson, M.P., Costello, M.J., O’Donnell, D. 1995. The nutrient economy of a marine inlet: Lough Hyne, south west Ireland. Ophelia 41, 137-151. 
[67] Kitching, J.A., Ebling, F.J. 1961. The ecology of Lough Ine. XI. The control of algae by Paracentrotus lividus (Echinoidea). J. Anim. Ecol. 30, 373-383.

[68] Broszeit, S., Davenport, J., Bredendieck, K., Harman, L., McAllen, R. 2013. Seasonal oxygen-driven migration of mobile benthic fauna affected by natural water column stratification. Est. Coastal Shelf Sci. $125,36-42$.

[69] Ebling, F.J., Sleigh, M.A., Sloane, J.F., Kitching, J.A. 1960. The ecology of Lough Ine: VII. Distribution of some common plants and animals of the littoral and shallow sublittoral regions. J. Ecol. 48, 29-53.

[70] Little, C., Morritt, D., Stirling, P. 1992. Changes in the shore fauna and flora of Lough Hyne. Ir. Nat. J. 24, 87-95.

[71] Little, C. 2011. Dabbling in the waters: 55 years in Lough Hyne's intertidal and shall subtidal. In: Davenport J, McAllen R (eds) Lough Hyne Marine Reserve @ 30. A conference reflecting on the past, present and future directions of research at the lough. School of BEES, University College Cork, p. 12.

[72] Little, C., Trowbridge, C.D. 2014. Lough Hyne 2014. Twenty years of intertidal and shallow subtidal monitoring. Report to the National Parks and Wildlife Service, Ireland.

[73] Trowbridge, C.D., Little, C., Pilling, G.M., Stirling, P., Miles, A. 2011. Decadal-scale changes in the shallow subtidal benthos of an Irish marine reserve. Bot. Mar. 54, 497-506.

[74] Trowbridge, C.D., Little, C., Dlouhy-Massengale, B., Stirling, P., Pilling, G.M. 2013. Changes in brown seaweed distributions in Lough Hyne, SW Ireland: a long-term perspective. Bot. Mar. 56, 323-338.

[75] Lee, G., Hwang, J., Chung, Y., Kim, D., Moh, S.H., Chang, M., Lee, T.-K. 2012. Effects of hypoxia on the fertilization and early development of sea urchin, Strongylocentrotus nudus. J. Korea Acad.-Industrial Coop. Soc. 13, 3785-3791.

[76] Stachowitsch, M. 1984. Mass mortality in the Gulf of Trieste: the course of community destruction. P.S.Z.N.I. Mar. Ecol. 5, 243-264.

[77] Stachowitsch, M. 1991. Anoxia in the Northern Adriatic Sea: rapid death, slow recovery. Pp. 119-129. In Modern and Ancient Continental Shelf Anoxia. Tyson, R.V. and Pearson, T.H. (eds.). Geological Soc. Spec. Pub. 58, London.

[78] Waheed, S. 2014. Investigation of the effect of Ectocarpus sp. on mortality and behaviour of a number of marine invertebrate species at Lough Hyne, Ireland. Dissertation, University College Cork.

[79] Menge, B.A., Olson, A.M. 1990. Role of scale and environmental factors in regulation of community structure. Trends Ecol. Evol. 5, 52-57. 
[80] Burkholder, J.M., Tomasko, D.A., Touchette, B.W. 2007. Seagrasses and eutrophication, J. Exp. Mar. Biol. Ecol. 350, 46-72.

[81] Breitburg, D. 2002. Effects of hypoxia, and the balance between hypoxia and enrichment, on coastal fishes and fisheries. Estuaries 25, 767-781.

[82] Tyler, R.M., Targett, T.E. 2007. Juvenile weakfish Cynoscion regalis distribution in relation to diel-cycling dissolved oxygen in an estuarine tributary. Mar. Ecol. Prog. Ser. 333, 257-269. 


\section{Figure Legends}

Fig. 1. Map of Lough Hyne in SW Ireland (modified from map 4 of Myers et al. 1991). Intertidal zone (stippled) and shallow subtidal habitats are subdivided into 108 topographically discrete sectors designated by shore (W, west; S, south; E, east, N, north; I, island) and sector number. a Location of 50-m transects surveyed in 2013. b Location of 5-m transects sampled in 2013. c Location of temporal variation in sampling with continuouslyrecording HOBO sensor and a YSI hand-held sensor. d Location of monitoring of oxygen levels above and below rocks in 2013 .

Fig. 2. Spatial variation of DO levels recorded along an onshore-offshore transect on a 27 Aug 2013 and b 13 Sep 2013 from different locations around the shore of Lough Hyne. Site codes refer to Renouf sector locations (see Fig. 1).

Fig. 3. Observed differences in dissolved oxygen concentrations above and below selected rocks in a Aug/Sep 2011 ( $\mathrm{n}=10$ rocks/site) and b Aug/Sep 2013 ( $\mathrm{n}=20$ rocks/site) at long-term monitoring sites in Lough Hyne, SW Ireland. Error bars represent SE and the dashed vertical line indicates oxygen saturation in air.

Fig. 4. Temporal variation in dissolved oxygen levels on 19-20 July 2012. Results are based on 6 replicate measurements per site, every 4 hours. Error bars denote $\pm 1 \mathrm{SE}$; in several cases, error bars are smaller than data symbol. Site codes refer to sector locations (see Fig. 1). Surface, water surface; interface, water-algal interface; tuft, inside clump of algae.

Fig. 5. Temporal variation in dissolved oxygen levels: a North shore (N11) on 19-20 Sep 2013 and b Codium Bay (S16) on 16-17 Sep 2013. Site codes refer to sector locations (see Fig. 1). Data based on HOBO data logger values recorded every $15 \mathrm{~min}$. The horizontal dashed lines indicate hypoxic conditions and gray box denotes nighttime. 

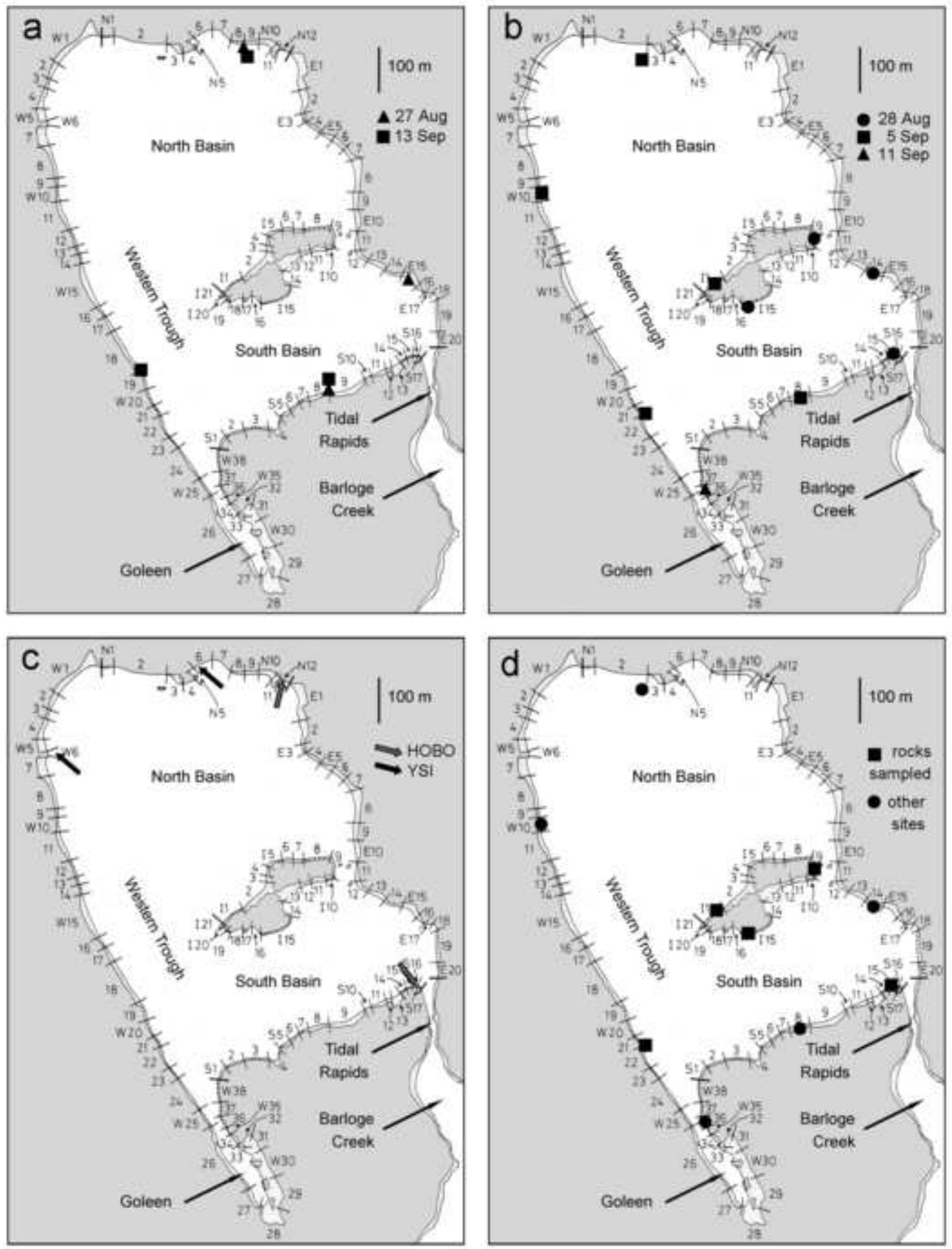

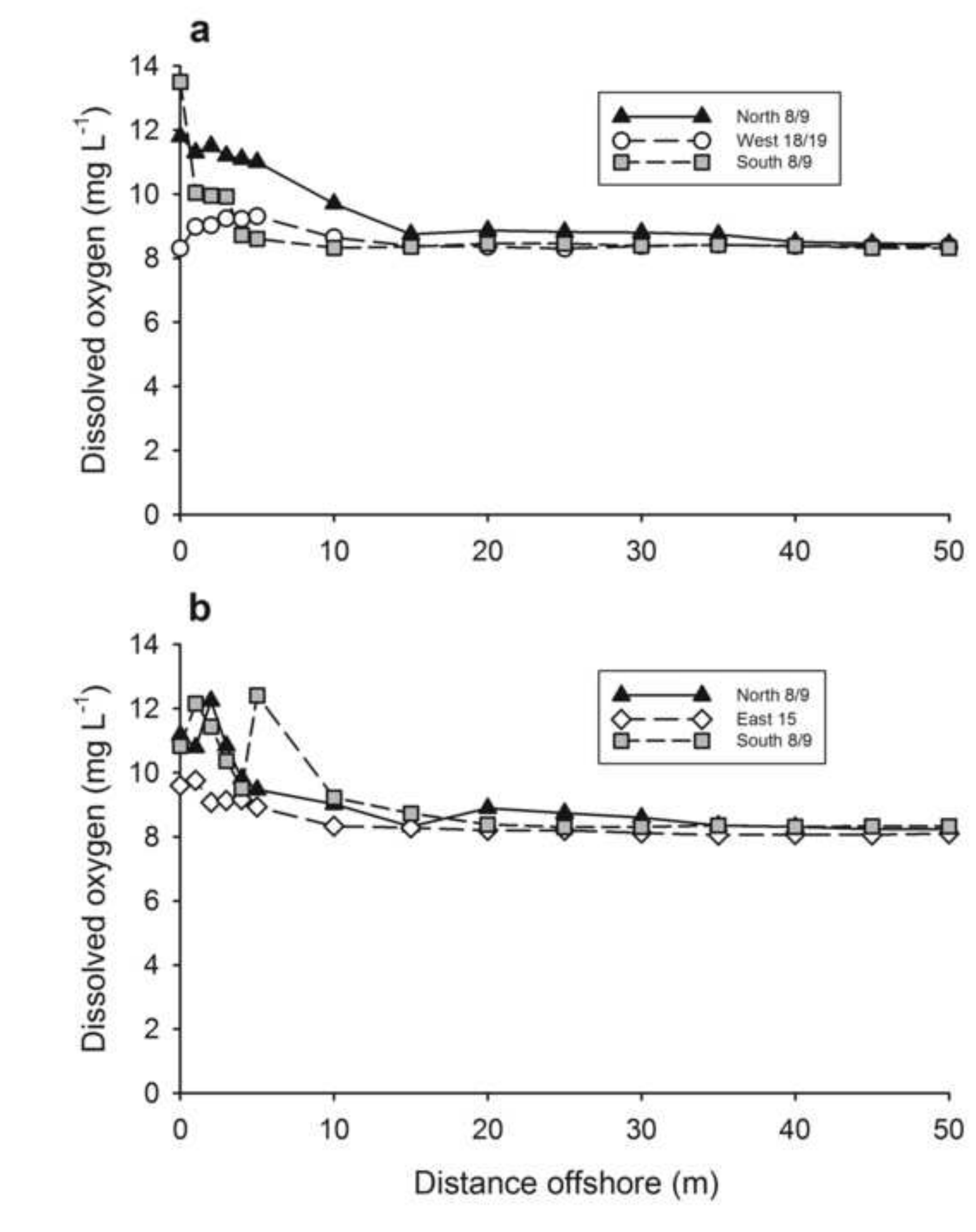

Figure 2

2

\section{Figure}

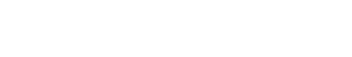

(
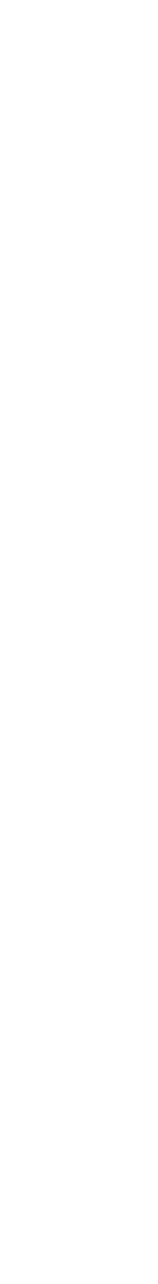

(



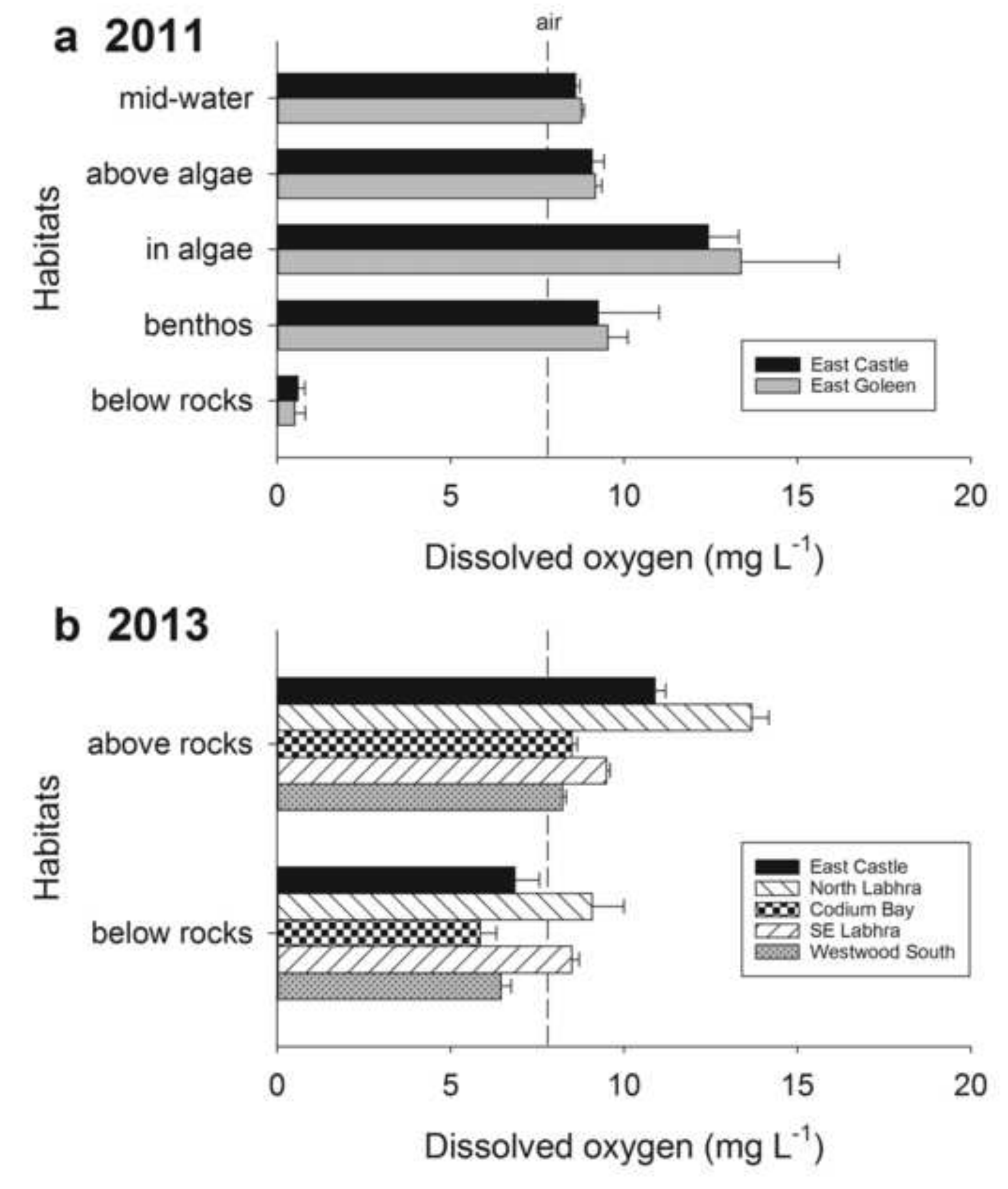

Figure 3

b 2013

$\frac{\pi}{\frac{\pi}{\pi}}$

below rocks

East Castle

East Goleen

Dissolved oxygen $\left(\mathrm{mg} \mathrm{L}^{-1}\right)$

above rocks

a 2011

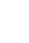

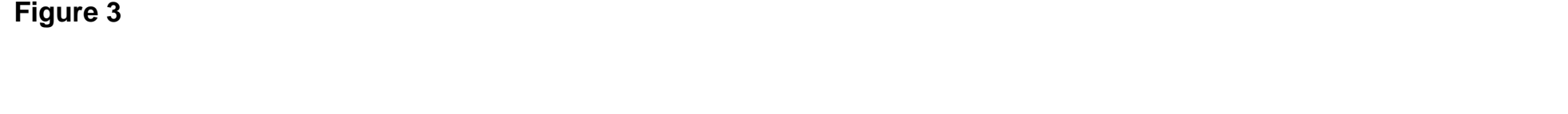


Figure 4
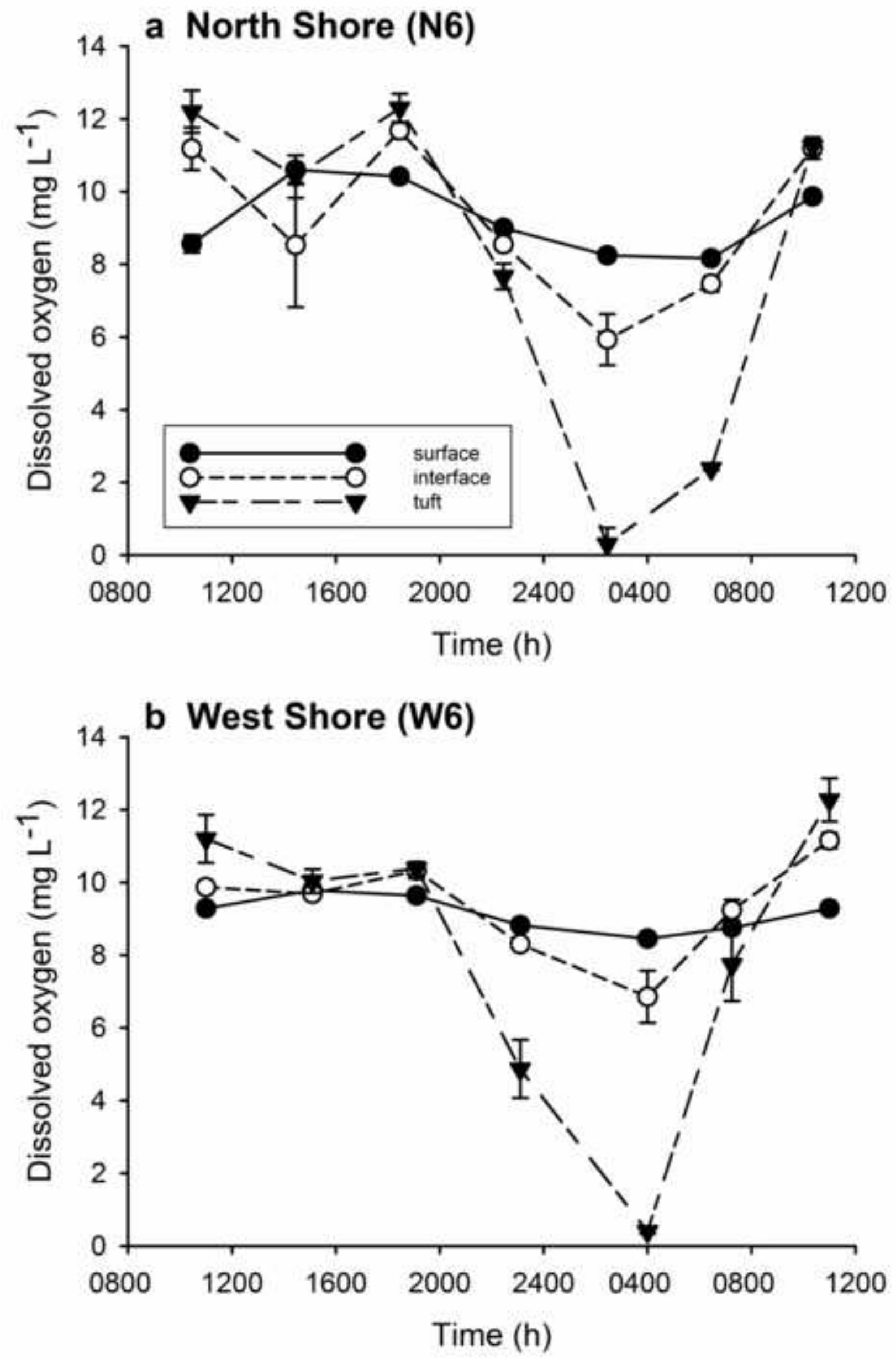
a North shore (N11)

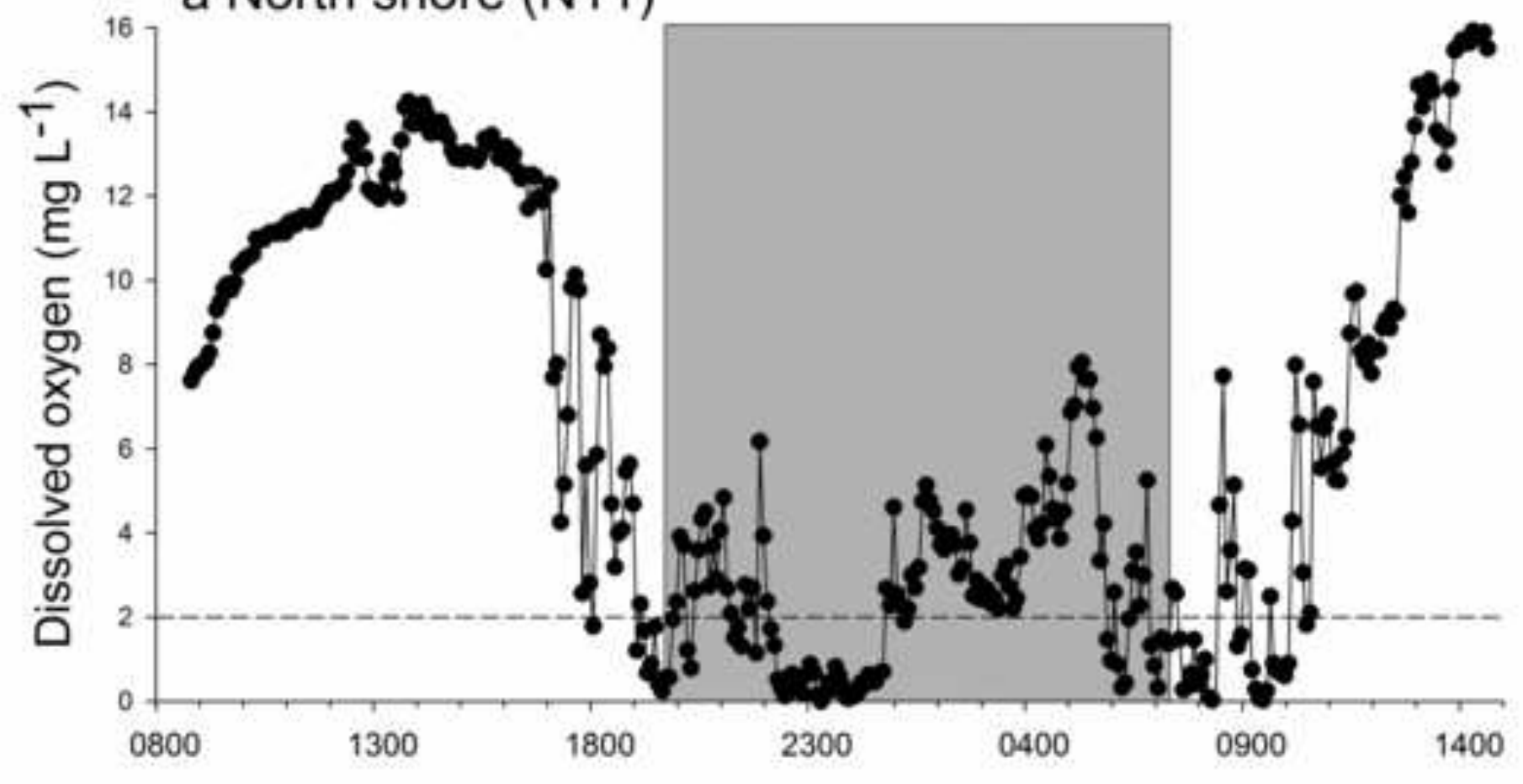

b Codium Bay (S16)

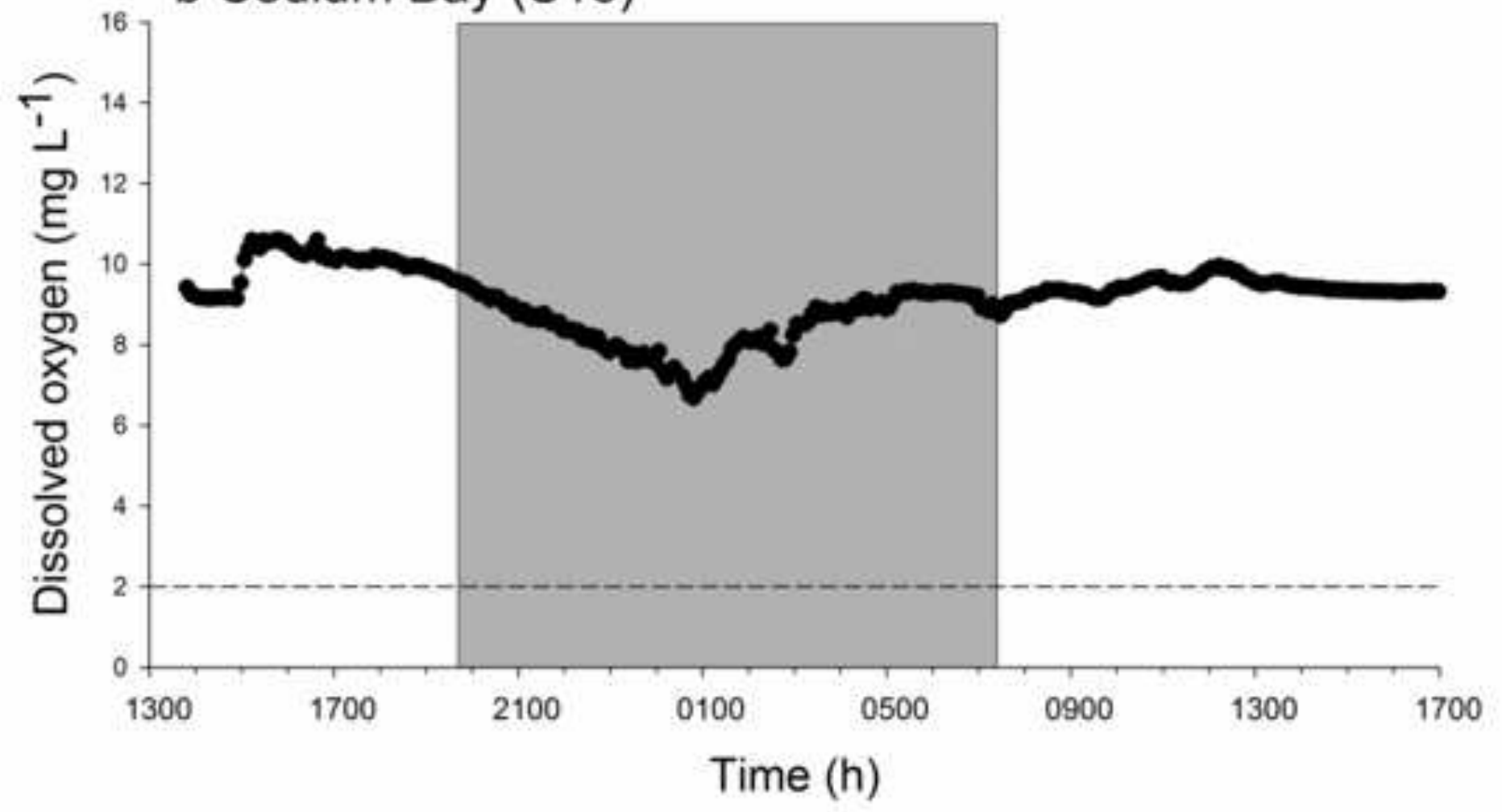

